SHeinin, R. (1958). J. gen. Microbiol. 19, 365-379

\title{
Formation of Enzymes Involved in Pyrimidine Synthesis and Amino Acid Metabolism in Escherichia coli
}

\author{
By ROSE SHEININ* \\ The Medical Research Council Unit for Chemical Microbiology, \\ School of Biochemistry, University of Cambridge
}

\begin{abstract}
SUMMARY: Escherichia coli B 10, a mutant strain of $E$. coli B, which exhibited a requirement for histidine + uracil under certain conditions of growth, became pyrimidine-independent when grown in a simple medium supplemented with these two substances. It was demonstrated that this change from uracil-dependence to non-dependence was not due to the selection of a competent back-mutant, but to the formation of the enzyme dihydro-orotic acid dehydrogenase, which is lacking in uracil-requiring organisms. A study of the enzyme content of mutant and wild type $\boldsymbol{E}$. coli at various stages of growth demonstrated that a high enzyme-forming capacity is associated with young organisms harvested from cultures in the late lag or early logarithmic period.
\end{abstract}

The growth of organisms is accompanied by qualitative and quantitative changes in their enzymic activities (Needham, 1942; Greenstein, 1947; Potter, 1950; Hardwick \& Foster, 1953; Dolphin \& Frieden, 1955). The enzyme composition appears to be dependent upon the age of the organisms (Gale, 1938; Rogers, 1954, 1957 ; Barnes \& Morris, 1957; Holmes, 1955; Sheinin, 1956) the physical conditions of their growth (Gale \& Epps, 1942; Gale, 1943; Rogers \& Spensley, 1955; Holmes, 1955; Goebl, Barry \& Shedlovsky, 1956; Giles, Partridge \& Nelson, 1957), as well as upon the constituents of the growth medium (Monod, 1942; Nason, Kaplan \& Oldewurtel, 1953; Spiegelman, 1950).

The results of investigation of induced enzyme formation (Cohn \& Monod, 1953; Pollock, 1953), enzyme inhibition (Yates \& Pardee, 1956 $b$ ) and enzyme repression (Vogel, 1956, 1957; Yates \& Pardee, 1957) suggest that any or all of these mechanisms may participate in moulding the enzyme pattern of organisms. Further study of this problem was made possible as a result of the finding, described in the present communication, that in the course of growth on uracil-containing medium an apparent uracil-requiring mutant of Escherichia coli acquired the ability to grow without an exogenous supply of pyrimidine.

\section{METHODS}

Organisms. Two organisms were used: (i) a laboratory strain of Escherichia coli B; (ii) a mutant of another strain of $E$. coli B, the mutant Escherichia coli B10, which requires for its growth histidine and, under certain conditions

\footnotetext{
* Present address : Ontario Cancer Institute, 500 Sherbourne Street, Toronto 5, Canada.
} 
(to be discussed), uracil or cytosine. This organism was obtained from Dr S. Brenner of the Medical Research Council Unit of Molecular Biology, University of Cambridge.

Media. Escherichia coli B 10 was maintained on slopes of a medium containing (w/v): $1 \%$ glucose, $0.1 \%$ Marmite (Marmite Ltd., London), $3 \%$ tryptic hydrolysate of casein (Gale, 1947) and $2 \%$ agar (Harrington Bros. Ltd., London). This medium will be referred to throughout as the $\mathrm{E}$ medium. Escherichia coli B was similarly maintained on C medium of Roberts et al. (1955) supplemented with glucose $(1 \%, w / v)$ and agar $(2 \%, w / v)$. In all cases inoculated slopes were incubated for $24 \mathrm{hr}$. at $37^{\circ}$ and then kept at room temperature for not longer than 1 week. These cultures were used to give inocula for experimental work.

In some instances large volumes of inoculum were required. To obtain these, organisms were cultured as above on solid medium in Roux bottles.

For growth experiments and enzyme analyses organisms were grown in liquid medium in volumes of $400 \mathrm{ml}$. in 11 . Florence flasks, shaken in water baths at $37^{\circ}$. The basal medium, which will be referred to throughout as the C/G medium, was the $\mathrm{C}$ medium (Roberts et al. 1955) containing glucose $(0 \cdot 2 \%, w / v)$. The other media, the $\mathrm{C} / \mathrm{G} / \mathrm{H}$ and $\mathrm{C} / \mathrm{G} / \mathrm{HU}$ media, consisted of C/G medium supplemented with L-histidine (Roche Products Ltd., $10 \mu \mathrm{g} . / \mathrm{ml}$.) and uracil (Light's Chemical Co., $10 \mu \mathrm{g} . / \mathrm{ml}$.) as indicated by $\mathrm{H}$ and $\mathrm{U}$ respectively.

Growth was estimated by measuring the optical density of a culture at $420 \mathrm{~m} \mu$ in a Beckmann DU spectrophotometer, unless otherwise indicated. It has been found (Sheinin, 1956) that the optical density of cultures of Escherichia coli B is directly proportional to the bacterial dry weight from early in the lag period of growth, throughout the logarithmic phase and into the early stationary phase.

Enzyme preparations. Enzyme activity was examined in extracts prepared in the following way. Organisms grown in liquid medium were harvested by centrifugation for $20 \mathrm{~min}$. at $\mathbf{4 0 0 0} \mathrm{rev}$./min. To harvest organisms grown on solid medium the growth on the surface of the agar was washed off with 10-15 ml. C medium and centrifuged. The organisms were washed with icecold distilled water and resuspended in a volume of the same, approximately equal to the volume of the deposited organisms.

The organisms were disrupted according to the conditions worked out by Dr R. Davies, using a transducer designed to be employed with the 25 kilocycle Mullard oscillator. Two ml. portions of the above bacterial suspension were added to the stainless steel cup. The outer jacket was kept packed with crushed ice so that the temperature of the suspension never rose above $5^{\circ}-8^{\circ}$. The suspension was subjected to supersonic vibrations for $1 \mathrm{~min}$.; this gave complete cell breakage. As viewed in the microscope, with phase contrast, the preparation consisted of large granules, debris and some ghosts; no intact organisms were detected.

The broken cell suspension (or combined suspension in cases where the volume of the original suspension was greater than $2.0 \mathrm{ml}$.) was centrifuged 
at $2^{\circ}$ for $5 \mathrm{~min}$. at $4600 \mathrm{~g}$. The supernatant fluid was removed and stored at $\mathbf{- 2 0 ^ { \circ }}$ pending enzyme assay.

The nature of the supernatant fluid varied, depending upon the age of the organisms from which it was obtained. Young organisms, from the lag phase and logarithmic phase of growth, yielded supernatant fluids which were clear, slightly viscous and a pale yellowy-pink in colour. The supernatant fluids from stationary phase organisms, whether grown on liquid or solid medium were turbid, viscous and a definite pink in colour. No attempt was made to fractionate the supernatant fluids, which will be referred to throughout as 'the enzyme preparations'.

Enzyme assays. The ureidosuccinic acid (USA) synthetase (Jones, Spector \& Lipmann, 1955), the dihydro-orotase (Lieberman \& Kornberg, 1954) and the dihydro-orotic acid (DHO) dehydrogenase (Lieberman \& Kornberg, 1953) were measured by methods based on those used by Yates \& Pardee (1957).

(i) Ureidosuccinic acid synthetase. Enzyme preparation (0.2 $\mathrm{ml}$.) was incubated in a small centrifuge tube at $37^{\circ}$, with $0 \cdot 1 \mathrm{M}$-potassium phosphate buffer pH 6.2, 0.03 M-aspartic acid (pH of stock solution adjusted to 6.2 with potassium hydroxide) and 0.02 M-lithium carbamyl phosphate (Jones et al. 1955). The last was added as a fine suspension in water. To terminate the reaction $\mathbf{2 . 0} \mathrm{ml}$. of trichloroacetic acid (TCA, $5 \%$, w/v) was added. After overnight storage at $2^{\circ}$ this reaction mixture was centrifuged; the clear colourless supernatant fluid was filtered under suction and the TCA was removed by extraction with three $5 \mathrm{ml}$. portions of ether.

The concentration of USA in the extracted filtrate was assayed on $1.0 \mathrm{ml}$. portions by the procedure of Koritz \& Cohen (1954) with slight modification. The diacetyl monoxime reagent was made up in $60 \%(\mathrm{v} / \mathrm{v})$ ethanol in water and $0.5 \mathrm{ml}$. potassium persulphate solution was added in the final stage. The colour formed was measured at $555 \mathrm{~m} \mu$, at which wavelength the absorption curve for the USA-colour complex exhibits a maximum.

(ii) Dihydro-orotase. Enzyme preparation $(0.2 \mathrm{ml}$.) was incubated as above with $0.07 \mathrm{M}$-sodium acetate buffer $(\mathrm{pH} \mathrm{5.5)}$ ) and $0.07 \mathrm{~m}$-USA ( $\mathrm{pH}$ of stock solution adjusted to $\mathbf{5 . 5}$ with sodium hydroxide). Enzyme activity was halted by adding $2.0 \mathrm{ml}$. of perchloric acid (PCA, $5 \%, \mathrm{w} / \mathrm{v})$. The precipitated reaction mixture was stored overnight at $2^{\circ}$. A filtrate of the supernatant fluid was obtained as above.

To measure the amount of $\mathrm{DHO}$ in the filtrate a $1.5 \mathrm{ml}$. portion was incubated with $1.5 \mathrm{ml}$. M-sodium hydroxide at room temperature in a Beckman silica cuvette. The optical density at $240 \mathrm{~m} \mu$ was measured at various time intervals. The initial rate of decrease in the ultraviolet absorption was found to bear a linear relationship to DHO concentration and was therefore used as a measure of this concentration.

(iii) Dihydro-orotic acid dehydrogenase. Enzyme preparation $(0 \cdot 2 \mathrm{ml}$.) was incubated as above with $0 \cdot 1 \mathrm{M}$-potassium phosphate buffer $(\mathrm{pH} 7 \cdot 88$ ), $15 \mu$ mole reduced diphosphopyridine nucleotide (Sigma Chemical Co.) and $15 \mu \mathrm{mole}$ orotic acid (Light's Chemical Co.). The dihydro-orotic acid formed was 
measured as described in (ii) in filtered supernatant fluids of PCA-precipitated reaction mixtures.

(iv) Aspartase and histidase. To measure the aspartase and the histidase activities of the enzyme preparation, $0.1 \mathrm{ml}$. was incubated as above with $0.05 \mathrm{M}$-potassium phosphate buffer $(\mathrm{pH} \mathrm{7.0}), 0.015 \mathrm{M}$ L-aspartic acid or L-histidine $\mathrm{HCl}$ (stock solutions made up in $0.05 \mathrm{M}$-phosphate buffer). To terminate the reaction a $1.0 \mathrm{ml}$. portion of the reaction mixture was added to the outer compartment of a Conway vessel (Conway, 1947) containing $1.0 \mathrm{ml}$. of $40 \%(\mathrm{w} / \mathrm{v})$ potassium hydroxide. The vessels were incubated at $37^{\circ}$ for at least $90 \mathrm{~min}$. to permit the ammonia released to distil over into the $2 \cdot 0 \mathrm{ml}$. of $\mathrm{N}$-hydrochloric acid in the centre well. One ml. portions of the ammonium chloride solution so formed were assayed for their nitrogen content by the procedure of Johnson (1941).

All measurements of enzyme activity were made in duplicate in reaction mixtures of a total volume of 1.2-1.5 ml., under conditions and for periods of time during which enzyme activity was linear. The enzyme activities are expressed throughout as $\mu$ mole product formed $/ \mathrm{hr}$. $/ \mathrm{mg}$. protein (measured by the method of Lowry, Roseborough, Farr \& Randall, 1951) in the enzyme preparation. Bovine plasma albumin (Armour Laboratories) was used as the standard protein.

\section{RESULTS}

\section{Uracil requirement of Escherichia coli mutant B 10}

Escherichia coli B10 grown on solid $\mathbf{E}$ medium and then subcultured into a simple ammonia salts medium (C medium) exhibited an absolute requirement for histidine + uracil. Even after incubation for as long as $48 \mathrm{hr}$. at $37^{\circ}$ the organism did not grow without uracil. However, when cultured in a fully supplemented medium (C/G/HU) $E$. coli B 10 acquired the ability to grow subsequently in the absence of added uracil (Fig. 1). Organisms harvested from an $\mathrm{E}$ medium slope were grown in $\mathrm{C} / \mathrm{G} / \mathrm{HU}$ medium at $37^{\circ}$ (curve 2 ). At various times portions of the culture were centrifuged, the organisms washed once with a large volume of $\mathrm{C}$ medium and suspended in the same to a constant optical density. Such suspensions of organisms were used to inoculate standard volumes of $\mathrm{C} / \mathrm{G} / \mathrm{H}$ medium. These cultures were shaken at $37^{\circ}$ for 24. $\mathrm{hr}$. and their optical density (at $420 \mathrm{~m} \mu$ ) was measured (curve 3).

Little or no change in the optical density of $\mathrm{C} / \mathrm{G} / \mathrm{H}$ cultures, inoculated with organisms from very young or very old cultures made in $\mathrm{C} / \mathrm{G} / \mathrm{HU}$, was observed. However, when $\mathrm{C} / \mathrm{G} / \mathrm{H}$ cultures were sown with organisms harvested from $\mathrm{C} / \mathrm{G} / \mathrm{HU}$ cultures in the logarithmic and early stationary phases, these exhibited different increases in optical density after $24 \mathrm{hr}$. It seems reasonable to conclude that the observed increases in optical density of all the cultures represent growth of the organism. Although no bacterial counts were made in these experiments, there is little doubt that the large changes in optical density were due to increases in numbers of organisms. However, it is possible that the small change in optical density observed when inocula from the late lag, early exponential and very late stationary phase 
were employed, was due not to multiplication but to a change in shape or size of the existing organisms brought about by growth of cellular constituents.

Thus it was concluded that as the Escherichia coli B10 cells grew in the C/G/HU medium, they lost their uracil dependence. The ability to grow subsequently without uracil (curve 3) increased as the culture passed through the logarithmic period (curve 2), reached a peak, and then declined as the original culture entered the stationary phase of growth.

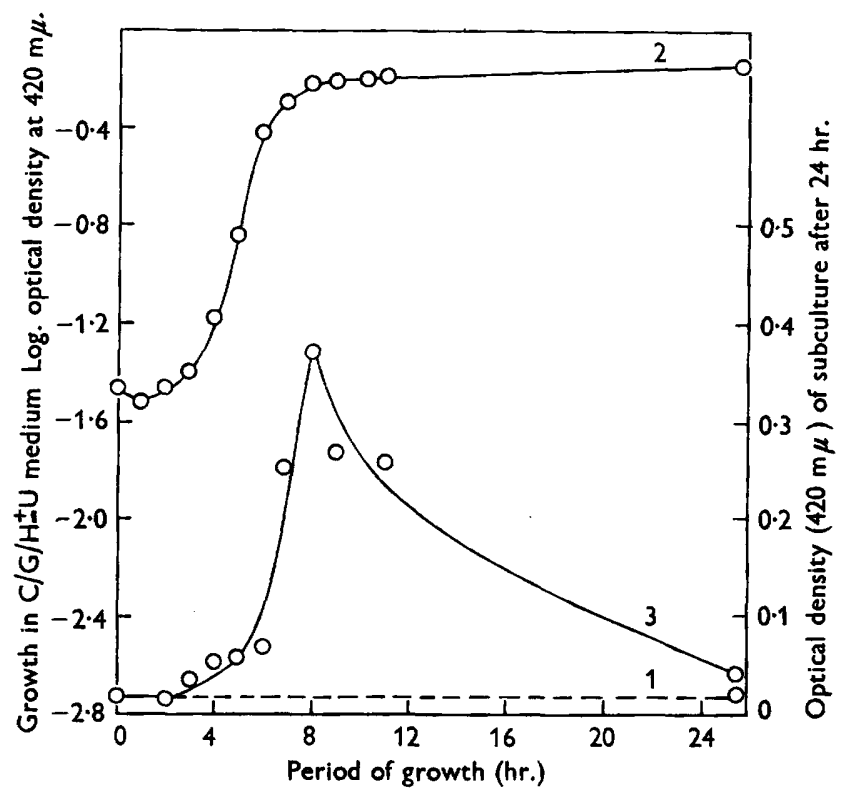

Fig. 1. Growth of Escherichia coli B 10 in defined medium in the absence of uracil. Curve 1 : growth of organisms subcultured from $\mathbf{E}$ medium slopes into $\mathrm{C}$ medium supplemented with glucose $(0.2 \%, \mathrm{w} / \mathrm{v})$ and histidine $(10 \mu \mathrm{g} . / \mathrm{ml}$.). Curve 2: growth of organisms cultured as in curve 1 in $\mathrm{C} / \mathrm{G} / \mathrm{H}$ medium containing added uracil (10 $\mu \mathrm{g} . / \mathrm{ml}$.). Curve 3 : optical density after $24 \mathrm{hr}$. of subcultures made in $\mathrm{C} / \mathrm{G} / \mathrm{H}$ medium of organisms harvested from the $\mathrm{C} / \mathrm{G} / \mathrm{HU}$ culture, the growth of which is shown in curve 2.

This phenomenon was not dependent upon the size of the inoculum used. The same kind of response (with some quantitative variations) was obtained whether a very large or a very small inoculum was used. In all cases the ability to grow without uracil was acquired by organisms in the course of their growth in the $\mathrm{C} / \mathrm{G} / \mathrm{HU}$ medium, and usually appeared early in the growth cycle.

This change from dependence on, to independence of, exogenous uracil suggested that in the course of their growth on a uracil-containing medium, the organisms acquired one or more enzymes which participated in the synthesis of pyrimidines. Before going on to study this phenomenon it was essential to be certain that it was not due to the selection of a back mutant, but was in fact associated with the growth of the original Escherichia coli B10. The hypothesis that the above experimental findings were due to selection of 
a back mutant able to synthesize uracil would seem to be excluded by a number of facts.

(a) The ability to grow without uracil, once acquired by the organisms, is not a stable characteristic, but is lost as the organisms continue to grow (Fig. 1).

(b) If competent back mutants had appeared during growth on the $\mathbf{E}$ medium agar, one would hope to provide them with a selective advantage for growth by inoculating $\mathrm{C} / \mathrm{G} / \mathrm{HU}$ medium with inocula of increasing size. However, in no instance was growth obtained, even after incubation for $48 \mathrm{hr}$., with inocula containing up to the order of $10^{10}-10^{12}$ organisms.

(c) That the selection of back mutants appearing in the course of growth in the $\mathrm{C} / \mathrm{G} / \mathrm{HU}$ medium seemed unlikely to explain the results was indicated by the data obtained in Fig. 1. Assuming back mutants had appeared one might postulate the following. (i) The growth rate of the mutant might be equal to that of Escherichia coli B 10; in this case the same number of mutant organisms should be present in each inoculum and therefore the $24 \mathrm{hr}$. optical density achieved in $\mathrm{C} / \mathrm{G} / \mathrm{H}$ medium should be the same irrespective of the age of the inoculum. (ii) The growth rate of the mutant might exceed that of the parent; in this case an increasing proportion of the inoculum should be mutant organisms; and again the $24 \mathrm{hr}$. culture density should be the same, being limited only by the maximum growth-supporting capacity of the medium and the growth characteristics of the organisms (Monod, 1949). (iii) The growth rate of the mutant might be less than that of the parent; in this case the maximum ability for growth without uracil should be observed at the time at which the mutant appears, and should decline thereafter. Clearly none of the postulates is in accord with the experimental findings.

One further attempt was made to test for a uracil-synthesizing back mutant. Organisms similar to those used to obtain curve 3, Fig. 1, were plated on $\mathrm{C} / \mathrm{G} / \mathrm{H}$ medium solidified with $2 \%(\mathrm{w} / \mathrm{v})$ agar. If the onset of uracil independence were associated with the appearance of a back mutant, and this mutant occurred at the rate at which most mutations in Escherichia coli have been found to occur (Lederberg, 1949), then by plating $10^{5}$ to $10^{7}$ organisms one would hope to pick up from one to 100 colonies/plate. Organisms harvested during the lag phase of growth in $\mathrm{C} / \mathrm{G} / \mathrm{HU}$ medium, which were unable to grow in $\mathrm{C} / \mathrm{G} / \mathrm{H}$ medium, yielded no colonies in the plating test (Table $\mathbf{1}$ ). However, organisms harvested once growth in the uracil-containing medium had begun, were capable of growth in non-uracil medium and gave rise to confluent growth on the plates. This result indicated that all, or certainly a majority, of the organisms plated were capable of growth without uracil, and that therefore the observed uracil-independent growth was not due to the selection of pyrimidine-synthesizing back mutants.

\section{Uracil utilization by Escherichia coli mutant B10}

A second possible explanation for the growth of Escherichia coli B10 in uracil-free medium is that in the course of their growth in the $\mathrm{C} / \mathrm{G} / \mathrm{HU}$ medium, the organisms take up and store, in a free or bound form, sufficient 
uracil to satisfy their needs when transferred to $\mathrm{C} / \mathrm{G} / \mathrm{H}$ medium. This hypothesis seems improbable in view of the small number of organisms which were subcultured and which subsequently gave rise to cultures of approximately $1 \mathrm{mg}$. dry wt. organisms/ml., therefore containing of the order of $23 \mu \mathrm{g}$. pyrimidine/ml. (Roberts et al. 1955). To examine this possibility further the uracil utilization by $E$. coli B 10 was followed. Organisms were incubated as

\section{Table 1. Subsequent growth of Escherichia coli $B 10$ previously grown in $\mathrm{C} / \mathrm{G} / \mathrm{HU}$ medium}

Washed organisms, harvested from $\mathbf{E}$ medium slopes, were grown in $\mathrm{C} / \mathrm{G} / \mathrm{HU}$ medium. After varying periods of incubation organisms were subcultured into liquid $\mathrm{C} / \mathrm{G} / \mathrm{H}$ medium and on to $\mathrm{C} / \mathrm{G} / \mathrm{H}$ agar plates; growth was assessed by optical density and colony counts respectively.

\begin{tabular}{|c|c|c|c|}
\hline $\begin{array}{l}\text { Duration of } \\
\text { growth in } \\
\text { C/G/HU (hr.) }\end{array}$ & $\begin{array}{l}\text { Optical density } \\
\text { of culture } \\
(420 \mathrm{~m} \mu)\end{array}$ & $\begin{array}{c}24 \mathrm{hr} \text { growth of } \\
\text { subculture in } \\
\mathrm{C} / \mathrm{G} / \mathrm{H}\end{array}$ & $\begin{array}{c}\text { Colony growth on } \\
\mathbf{C} / \mathbf{G} / \mathbf{H} \text { agar }\end{array}$ \\
\hline $\mathbf{0}$ & $0 \cdot 006$ & None & None \\
\hline 1 & 0.006 & None & None \\
\hline 4 & 0.006 & None & None \\
\hline 7 & 0.057 & + & Confluent growth \\
\hline 9 & 0.394 & $+t+$ & Confluent growth \\
\hline
\end{tabular}

in curve 2, Fig. 1. At different times portions of the culture containing the equivalent of 1-10 mg. dry wt. organisms were chilled and centrifuged at $20,000 \mathrm{~g}$ at $2^{\circ}$ for $15 \mathrm{~min}$. The optical density at $260 \mathrm{~m} \mu$ of the culture supernatant fluid was taken as an index of the uracil content. The pellet of organisms was extracted first with $5 \mathrm{ml} .5 \%(\mathrm{w} / \mathrm{v})$ perchloric acid at $2^{\circ}$ for $2 \mathrm{hr}$., and then with $5 \mathrm{ml} .5 \%(\mathrm{w} / \mathrm{v})$ perchloric acid at $70^{\circ}$ for $30 \mathrm{~min}$. The u.v. absorption of the extracts was taken as a measure of the amount of free purines + free pyrimidines + nucleotides in the first case, and of the nucleic acid content of the organisms in the second. The results obtained are shown in Fig. 2.

No detectable disappearance of uracil (Fig. 2, curve $b$ ) occurred until growth had begun (Fig. 2, curve a). The decrease in uracil content of the medium appeared to be directly related to the growth of the organism. The study of uracil utilization beyond $3 \mathrm{hr}$. was obscured by the appearance in the medium of some u.v. absorbing material. However, it is clear from curve $c$ that the organisms did not store large amounts of uracil either in free or nucleotide form. If the organisms were enabled to grow in uracil-free medium as a result of their storage of pyrimidine, then one would have expected that the concentration of cold perchloric acid-soluble substances should increase as the organism grows in $\mathrm{C} / \mathrm{G} / \mathrm{HU}$ medium; whereas in fact the amount of such materials decreased exponentially throughout the growth period. Similarly, curve $d$ indicates that there was no tendency for the storage of uracil as nucleic acid.

\section{Enzyme activity of Escherichia coli mutant B10}

To assess the biochemical nature of the change from uracil dependence to independence a study was made of the enzyme constitution of the organisms. The enzymes investigated were the ureidosuccinic acid synthetase (USA), the 
dihydro-orotase and the dihydro-orotic acid (DHO) dehydrogenase, which are known to participate in pyrimidine synthesis in $E$. coli (Yates \& Pardee, $1956 a$ ). In addition, in view of their possible involvement under the present experimental conditions, the aspartase (Gale, 1938) and histidase (Leuthardt, $1950)$ activities of the organisms were also examined.
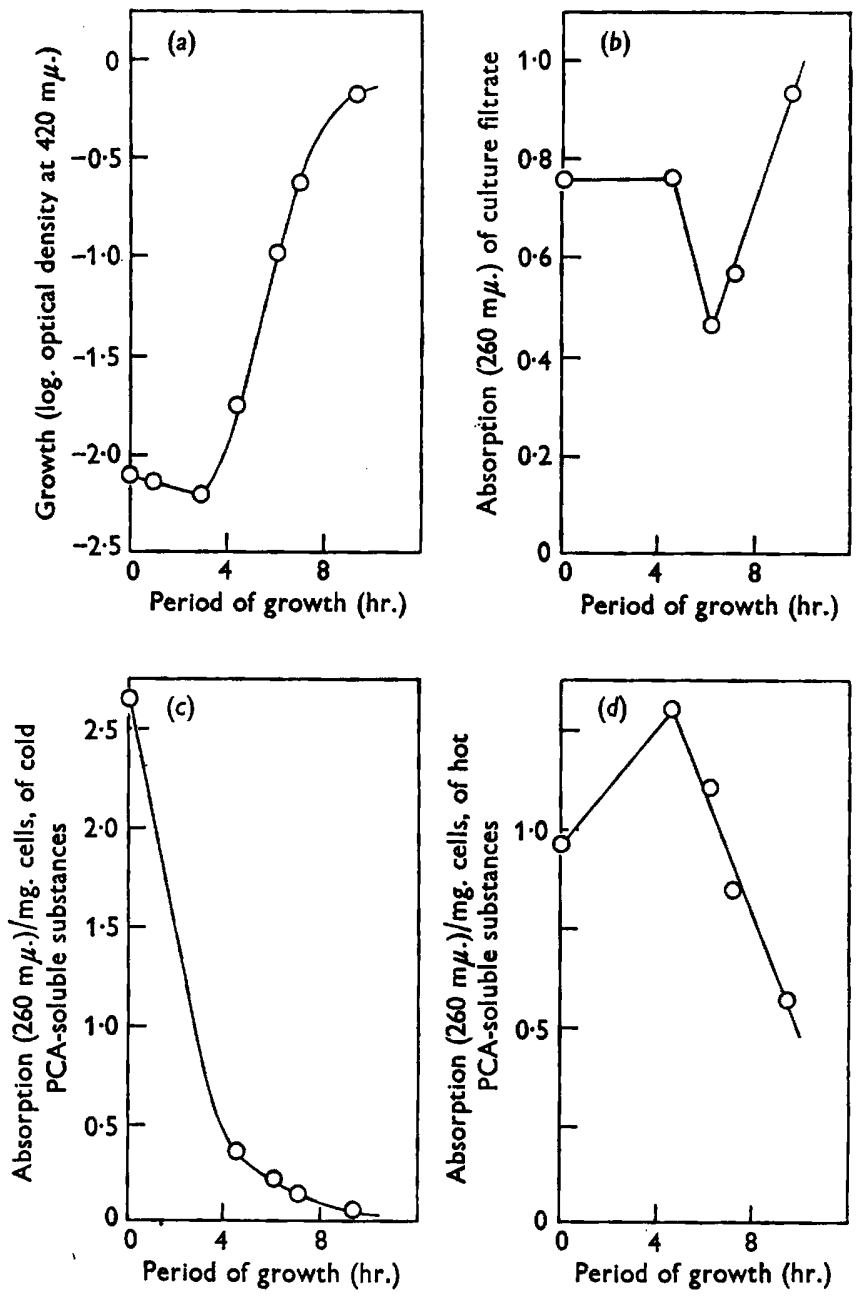

Fig. 2. Utilization of uracil by Escherichia coli B10. (a) Growth of organisms in C/G/HU medium; (b) ultraviolet absorption of culture filtrate; $(c)$ ultraviolet absorption of the cold PCA-soluble substances in $E$. coli B 10; $(d)$ ultraviolet absorption of the hot PCAsoluble substance in $\boldsymbol{E}$. coli B 10.

The activity of the amino acid deaminases, the USA synthetase and the dihydro-orotase, although low in the inoculum, rose to reach a maximum early in the logarithmic phase of growth, and then declined (Fig. 3). The E. coli B 10 organisms which were initially devoid of DHO dehydrogenase activity, acquired this activity during growth in the $\mathrm{C} / \mathrm{G} / \mathrm{HU}$ medium (Fig. $3 a$ ). Since the detection of DHO dehydrogenase activity depends on the 
availability of orotic acid it was possible that the absence of activity from the organisms of the inoculum might be due to the rapid removal of the substrate by some other metabolic pathway. This explanation was excluded by two findings: (i) under the test conditions used there was little or no orotic acid
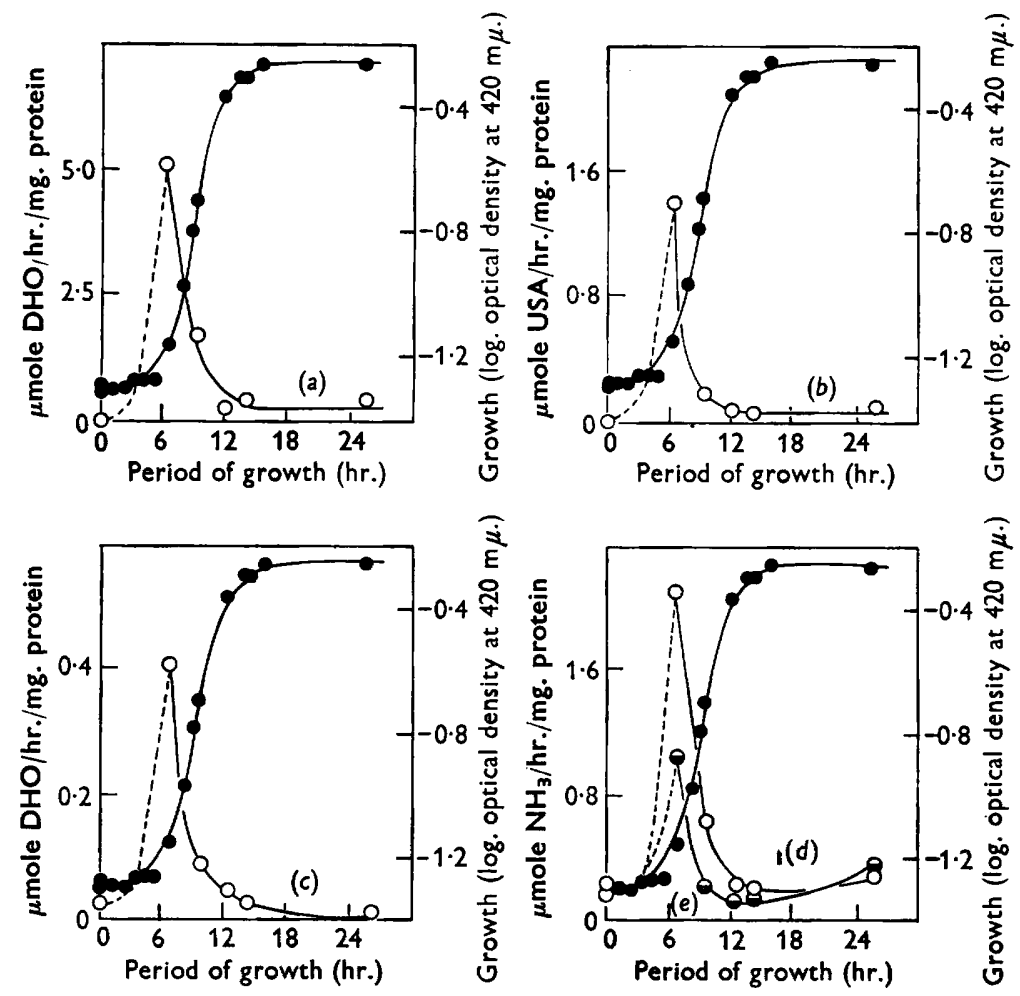

Fig. 3. Enzyme formation in Escherichia coli $\mathrm{B} 10$ grown in $\mathrm{C} / \mathrm{G} / \mathrm{HU}$ medium. growth; $\bigcirc-\mathrm{O}, \ominus-\ominus$, enzyme activity. (a) Dihydro-orotic acid dehydrogenase; (b) ureidosuccinic acid synthetase; (c) dihydro-orotase; $(d)$ aspartase; (e) histidase.

decarboxylase activity; (ii) in the absence of added reduced diphosphopyridine nucleotide, the optical density of the perchloric acid-extract of the reaction mixture remained essentially unchanged, indicating that the orotic acid remained unutilized. Thus the inability to detect DHO dehydrogenase activity in the inoculum does reflect an absence of such enzyme activity in the enzyme preparation.

To determine the relationship between the appearance of DHO dehydrogenase activity and the loss of uracil dependency, a closer examination was made of organisms in the lag period, with the results shown in Fig. 4. Those organisms which could not grow when subcultured into $\mathrm{C} / \mathrm{G} / \mathbf{H}$ medium exhibited no detectable dehydrogenase activity; whereas organisms able to grow without added uracil did possess measurable dehydrogenase activity. The activity of the other enzymes studied, low throughout the early lag period, increased as the organisms began to grow in the $\mathrm{C} / \mathrm{G} / \mathrm{HU}$ medium. 

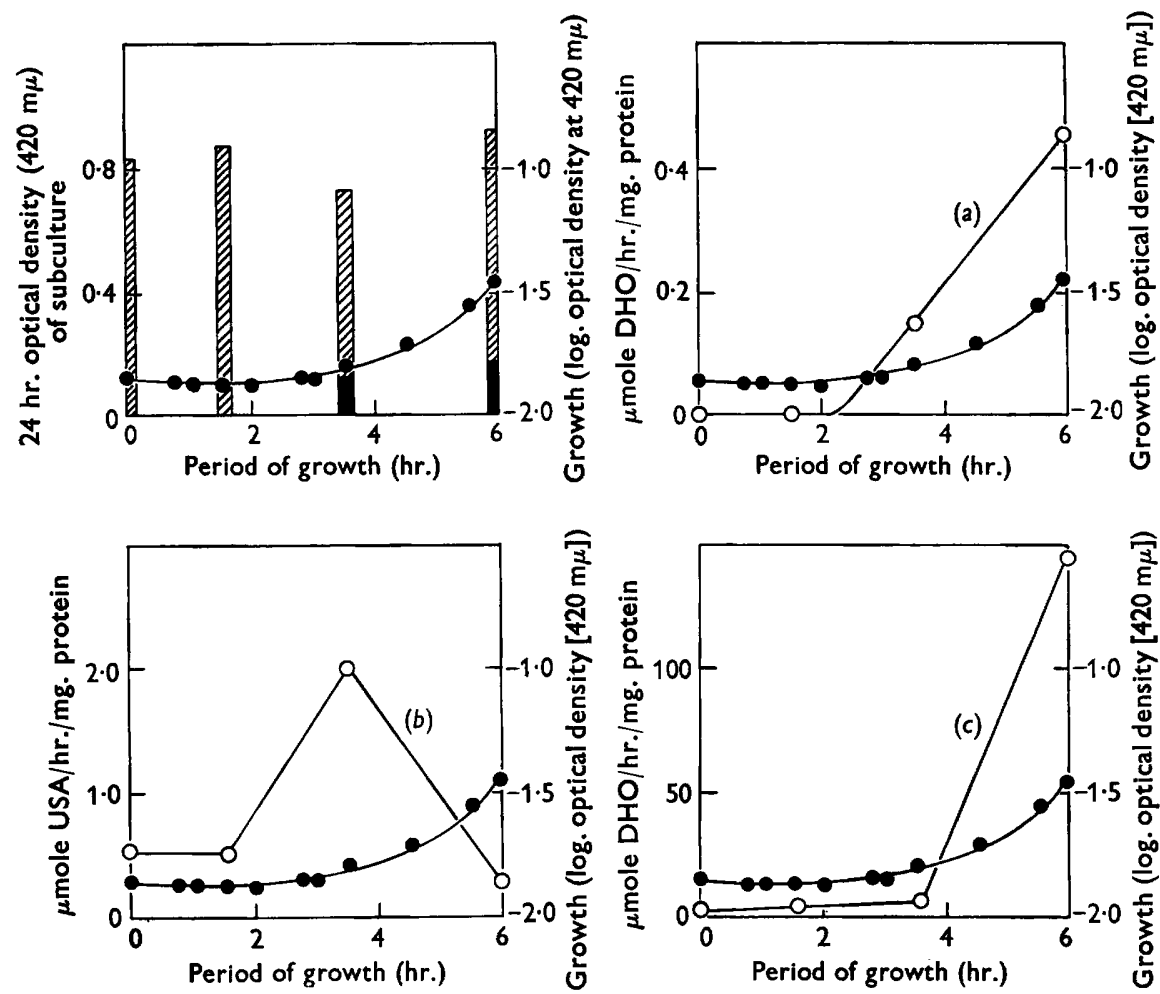

Fig. 4. The relationship between the enzyme activity of Escherichia coli B10 grown in C/G/HU medium and their capacity for growth without added uracil. The crosshatched bar graphs represent subsequent $24 \mathrm{hr}$. growth in $\mathrm{C} / \mathrm{G} / \mathrm{HU}$ medium, and the dark bar graphs subsequent 24 hr. growth in $\mathrm{C} / \mathrm{G} / \mathrm{H}$ medium, of organisms harvested from a C/G/HU culture, the growth of which is shown in curves - Enzyme activity is denoted by the curves $\mathrm{O}-\mathrm{O} ;(a)$ dihydro-orotic acid dehydrogenase; (b) ureidosuccinic acid synthetase; (c) dihydro-orotase.

Table 2. Comparison of the enzyme activities of Escherichia coli $B$ grown with and without uracil

Washed organisms harvested from $\mathbf{E}$ medium slopes, were subcultured into $\mathrm{C} / \mathrm{G} / \mathbf{H}$ medium with $(+)$ and without $(-)$ added uracil. Enzyme activities are expressed as $\mu$ moles product formed $/ \mathrm{hr} . \mathrm{mg}$. protein.

\begin{tabular}{|c|c|c|c|c|c|c|c|c|c|c|}
\hline \multirow{2}{*}{$\begin{array}{l}\text { Phase of growth } \\
\text { at which } \\
\text { organisms were } \\
\text { harvested }\end{array}$} & \multicolumn{2}{|c|}{ Aspartase } & \multicolumn{2}{|c|}{ Histidase } & \multicolumn{2}{|c|}{$\begin{array}{c}\text { succinic } \\
\text { acid } \\
\text { synthetase }\end{array}$} & \multicolumn{2}{|c|}{$\begin{array}{l}\text { Dihydro- } \\
\text { orotase }\end{array}$} & \multicolumn{2}{|c|}{$\begin{array}{l}\text { orotic acid } \\
\text { dehydro- } \\
\text { genase }\end{array}$} \\
\hline & - & + & - & + & - & + & - & + & - & + \\
\hline arly & $6 \cdot 28$ & & & & & & & & & $13 \cdot 6$ \\
\hline lid & $6 \cdot 5$ & 26 & 9 & & 0.46 & $0 \cdot 3$ & .69 & 12 & .35 & 0.9 \\
\hline & $3 \cdot 8$ & & 1.2 & & 0.09 & 0 . & 7 & & .09 & $\mathbf{0 \cdot 3}$ \\
\hline & 0.7 & 12 & 65 & & 0.04 & 0.0 & $3 \cdot 37$ & 0.2 & $\cdot 18$ & $0.5 ?$ \\
\hline ate stati & $0 \cdot 38$ & $14 \cdot 1$ & 4.53 & $6 \cdot 10$ & 0.02 & 0.09 & $2 \cdot 32$ & 0.21 & 0.14 & 0.54 \\
\hline
\end{tabular}


Enzyme activity of Escherichia coli $\boldsymbol{B}$

In order to be certain that the absence of DHO dehydrogenase activity from the Escherichia coli mutant B10 organisms was not an artifact, it was essential to know whether DHO dehydrogenase activity could be expressed under the experimental conditions employed. To test this the above experiment was repeated with the wild type $E$. coli B (Fig. 5). It is clear that
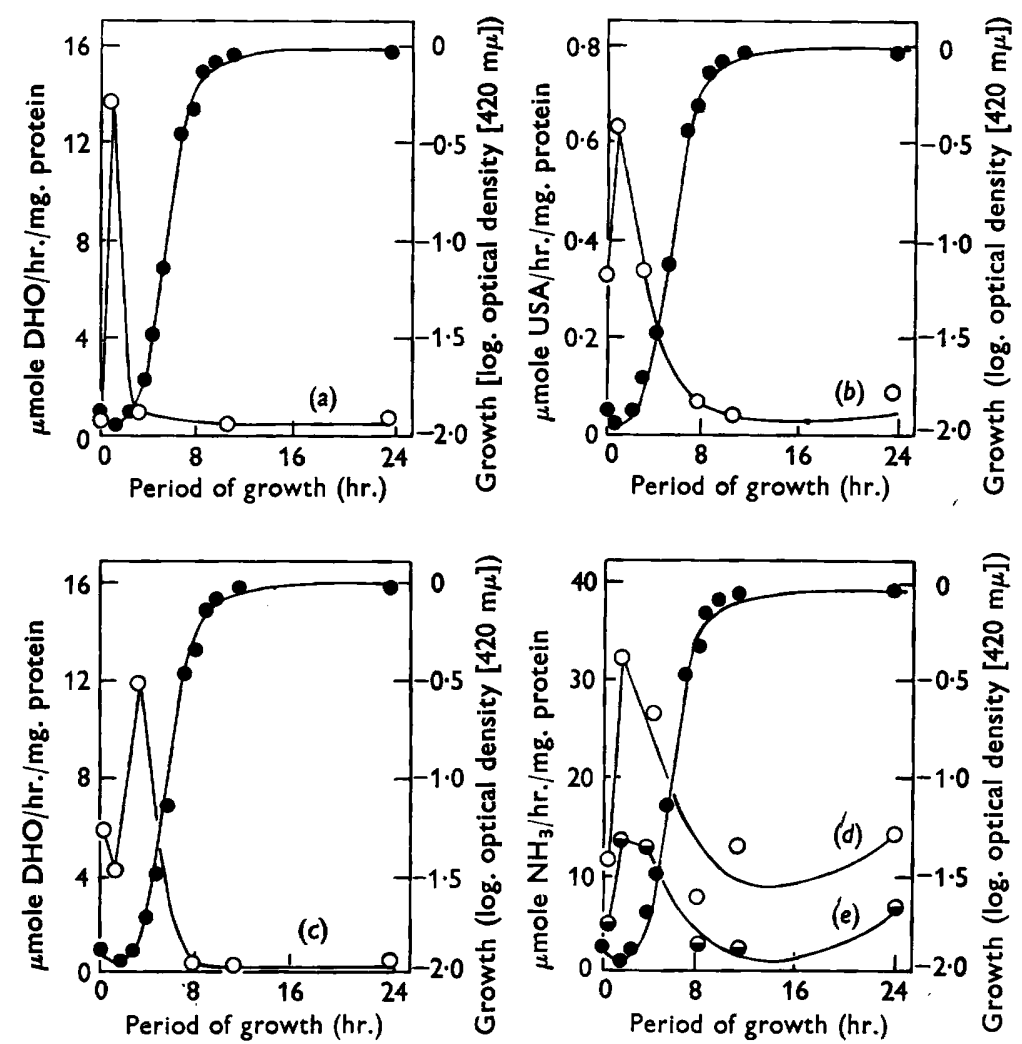

Fig. 5. Enzyme formation in Escherichia coli $\mathrm{B}$ grown in $\mathrm{C} / \mathrm{G} / \mathrm{HU}$ medium. $-\rightarrow$ growth; ○-O, $\diamond-\ominus$, enzyme activity; $(a)$ dihydro-orotic acid dehydrogenase; $(b)$ ureidosuccinic acid synthetase; $(c)$ dihydro-orotase; $(d)$ aspartase; $(e)$ histidase.

growth of the $E$. coli $\mathrm{B}$ on $\mathrm{E}$ medium agar did not result in the complete suppression of its DHO dehydrogenase activity. As in the case of $E$. coli mutant B 10 the enzyme pattern of $E$. coli $\mathbf{B}$ organisms differed at different times during growth. Qualitatively similar results were obtained when $E$. coli B was grown with or without added uracil, although quantitative differences were observed (Table 2).

\section{Test for inhibitor of dihydro-orotic acid dehydrogenase activity}

To test whether the absence of DHO dehydrogenase activity from some Escherichia coli B 10 extracts was due to the absence of active enzyme or to 
the presence of an enzyme inhibitor, the activity of an active preparation was measured in the presence of an inactive extract; this did not alter its activity (Table 3). Thus it is clear that an inhibitor of DHO dehydrogenase activity was not present in the inactive $\boldsymbol{E}$. coli B10 extract. In addition the active preparation does not appear to contain a dissociable activator or cofactor capable of influencing the inactive extract.

\section{Table 3. Dihydro-orotic acid dehydrogenase activity of extracts of Escherichia coli}

Aqueous extracts of $E$. coli $\mathrm{B}$ and $\boldsymbol{E}$. coli $\mathrm{B} 10$ grown in C/G/HUं were obtained from organisms disrupted by ultrasonic vibrations.

\begin{tabular}{|c|c|c|}
\hline Extract used & $\begin{array}{l}\text { Volume of } \\
\text { extract (ml.) }\end{array}$ & $\begin{array}{l}\text { dehydrogenase } \\
\text { activity ( } \mu \text { mole } \\
\text { dihydro-orotic } \\
\text { acid/hr.) }\end{array}$ \\
\hline E. coli B10 & $0 \cdot 10$ & $0 \cdot 000$ \\
\hline E. coli B & $0 \cdot 10$ & $0 \cdot 151$ \\
\hline $\left.\begin{array}{l}\text { E. } \operatorname{coli} \mathrm{B}+ \\
\text { E. } \operatorname{coli} \mathrm{B} 10\end{array}\right\}$ & $\begin{array}{l}0.10 \mathrm{ml} \\
\text { of each }\end{array}$ & $0 \cdot 157$ \\
\hline
\end{tabular}

\section{DISCUSSION}

Initially unable to grow without an exogenous supply of pyrimidine, Escherichia coli mutant B10 acquires the ability to do so when grown with uracil. In undergoing this change from uracil requirement to non-requirement, the organisms, which were devoid of dihydro-orotic acid dehydrogenase activity, acquire the capacity for converting dihydro-orotic acid into orotic acid. The finding (Table 3) that the absence of dihydro-orotic acid dehydrogenase activity in the inactive $E$. coli B10 extracts is not due to the presence of an inhibitor or the lack of an activator, makes it likely that the appearance of dehydrogenase activity in the organisms in the course of growth is due to the formation of active enzyme protein. The limitation of the assay procedure makes it difficult to conclude whether the change from non-active to active extract is qualitative, or whether it is a quantitative change from an extremely low, unmeasurable, amount of dihydro-orotic acid dehydrogenase in the former instance. However, whether the enzyme is lacking, or is present in such small quantity as to make it inadequate to satisfy the multiple pyrimidine requirements of the organism, the result is the same, namely, failure to grow and multiply unless there is a ready source of preformed pyrimidine. Once provided with this, the organisms can synthesize the nucleic acid-containing machinery which appears to be essential for enzyme formation (Gale, 1955), and then proceed to form not only the missing dihydro-orotic acid dehydrogenase, but also other enzyme proteins.

It seems clear that the capacity for pyrimidine synthesis is not the only factor which controls the growth of Escherichia coli B10. For although the ability to grow without added uracil appears to be dependent upon the presence in the organisms of active dihydro-orotic acid dehydrogenase (Fig. 4), there is not a direct correlation between the cellular concentration of dehydro- 
genase and the maximum growth achieved in non-uracil medium. It is perhaps not pyrimidine synthesis as such, but the formation of some pyrimidine cofactor or metabolic intermediate, which is the ultimate controlling factor in the growth of $\boldsymbol{E}$. coli B10 in the absence of added uracil.

A problem as yet unsolved, but emphasized by many investigations (Gale, 1943; Pollock, 1953; Vogel, 1957) is raised once more by the present studies; viz. what is it that stimulates, directs and controls the formation of the constitutive enzymes and the low basal level of the inducible enzymes, which normally comprise the metabolic and developmental machinery of a living cell. Although hypotheses involving enzyme repression (Vogel, 1956, 1957) may be invoked to explain the de novo formation of dihydro-orotic acid dehydrogenase these must await further experimental study.

However, one fact emerges from this investigation: uracil does not repress the formation of the pyrimidine-synthesizing enzymes in Escherichia coli B or in $E$. coli $\mathrm{B} 10$ grown on a simple medium. On the contrary enzyme formation in these organisms rises sharply in the course of their growth into the exponential phase. The general decrease in specific enzyme activity which occurs in the late logarithmic period may reflect a cessation of enzyme formation and/or an instability of enzyme protein brought about by factors associated with depletion of the medium originally capable of supplying the uracil, histidine and glucose requirements for a culture of maximum population equivalent to $1 \mathrm{mg} . / \mathrm{ml}$. dry weight organism. This explanation is supported by the observation of Gale (1938), that whereas the specific aspartase activity of $E$. coli grown on a rich medium rose to reach a plateau maximum, the specific aspartase activity of organisms grown on a simple medium increased throughout the exponential period of growth to reach a peak, and then declined sharply during the stationary phase.

The absence of suppression of enzyme formation by uracil seems to be at variance with the observations made by Yates \& Pardee (1957). However, these authors failed to take into account the different rates of growth of the mutant organisms studied, on media either lacking or supplemented with uracil or its precursors. If the specific enzyme activity of these organisms varied with growth in a manner similar to that observed with Escherichia coli B and $E$. coli B 10, then it is likely that the different rates of growth obtained under their experimental conditions would be sufficient to account for the marked differences in enzyme content of the organisms. This difference is not due primarily to specific inhibition of enzyme formation by uracil, but appears to be a secondary phenomenon dependent upon growth.

The author wishes to extend her deep appreciation to all the members of the Medical Research Council Unit for Chemical Microbiology, School of Biochemistry, University of Cambridge, and in particular to Dr K. McQuillen and Dr E. F. Gale, F.R.S., for their kind hospitality and for their many critical comments and suggestions during the course of this work. The financial support of the British Empire Cancer Campaign in the form of an exchange fellowship is gratefully acknowledged.

The author is a fellow of the National Cancer Institute of Canada. 


\section{REFERENCES}

Barnes, E. H. \& Morris, J. F. (1957). A quantitative study of the phosphase activity of Micrococcus pyogenes. J. Bact. 73, 100.

Corn, M. \& Monod, J. (1953). Specific inhibition and induction of enzyme biosynthesis. Symp. Soc. gen. Microbiol. 3, 133.

Conway, E. J. (1947). Microdiffusion Analysis and Volumetric Error, chapter II. London: Crosby Lockwood and Son, Ltd.

Dolphin, J. L. \& FrIEden, E. (1955). Biochemistry of amphibian metamorphosis. II. Arginase activity. J, biol. Chem. 217, 735 .

GALE, E. F. (1938). Factors influencing bacterial deamination. III. Aspartase: its occurrence in and extraction from Bact. coli and its activation by adenosine and related compounds. Biochem. J. 32, 1583.

GaLE, E. F. (1943). Factors influencing the enzymic activities of bacteria. Bact. Rev. 7, 139.

GaLE, E. F. (1947). The Chemical Activities of Bacteria, p. 17. London: University Tutorial Press Ltd.

Gale, E. F. (1955). From amino acids to proteins. In Symposium on Amino Acid Metabolism, p. 171. Edited by W. D. McElroy and B. Glass. Baltimore: Johns Hopkins Press.

GaLe, E. F. \& Eprs, H. M. R. (1942). The effect of the pH of the medium during growth on the enzymic activities of bacteria (Bact. coli and Micrococcus lysodeikticus) and the biological significance of the changes produced. Biochem. $J$. 36, 600.

Giles, N. H., Partridge, C. W. H. \& Nelson, N. J. (1957). The genetic control of adenylosuccinase in Neurospora crassa. Proc. nat. Acad. Sci., Wash. 43, 305.

Goert, W. F., Barry, G. T. \& Shedlovsky, T. (1956). Colicine K. I. The production of colicine $\mathrm{K}$ in media maintained at constant pH. J. exp. Med. 103, 577.

Greenstein, J. P. (1947). Biochemistry of Cancer. New York: Academic Press Inc.

HARDwICK, W. A. \& Foster, J. W. (1953). Enzymatic changes during sporogenesis in some aerobic bacteria. J. Bact. 65, 355.

HoLmes, R. (1955). The Mechanism of the Biosynthesis of Enzymes. Ph.D. Thesis, University of Toronto.

Johnson, M. J. (1941). Isolation and properties of a pure yeast polypeptidase. J. biol. Chem. 137, 575 .

Jones, M. E., Spector, L. \& Lipmann, F. (1955). Carbamyl phosphate, the carbamyl donor in enzymatic citrulline synthesis. J. Amer. chem. Soc. 77, 819.

Koritz, S. B. \& Cohen, P. P. (1954). Colorimetric determination of carbamylamino acids and related compounds. J. biol. Chem. 209, 145.

Lederberg, J. (1949). Bacterial variation. Annu. Rev. Microbiol. 3, 1.

Leuthardt, F. (1950). Histidase and urocanase. In The Enzymes, vol. r, pt. 2, p. 1156. Edited by J. B. Sumner and K. Myrbäck. New York: Academic Press Inc.

Lieberman, J. \& Kornberg, A. (1953). Enzymic synthesis and breakdown of a pyrimidine, orotic acid. I. Dihydroorotic dehydrogenase. Biochim. biophys. Acta, 12, 223.

LIEBERMAN, J. \& KorNBerg, A. (1954). Enzymatic synthesis and breakdown of a pyrimidine, orotic acid. II. Dihydroorotic acid, ureidosuccinic acid, and 5-carboxymethylhydantoin. J. biol. Chem. 207, 911.

Lowry, O. H., Roseborough, N. J., Farr, A. L. \& Randall, R. J. (1951). Protein measurement with the Folin Phenol reagent. J. biol. Chem. 193, 265.

Monod, J. (1942). Récherches sur la croissance des cultures bactériennes. Paris: Hermann \& Cie. 
Monod, J. (1949). The growth of bacterial cultures. Annu. Rev. Microbiol. 3, 371.

Nason, A., Kaplan, N. O. \& Oldewurtel, H. A. (1953). Further studies of nutritional conditions affecting enzymatic constitution in Neurospora. J. biol. Chem. 201, 435.

Needham, J. (1942). Biochemistry and Morphogenesis. Cambridge University Press.

Pollock, M. R. (1953). Stages in Enzyme Adaptation. Symp. Soc. gen. Microbiol. $3,150$.

Potter, van R. (1950). Enzymes, Growth and Cancer. Springfield: Chas. C. Thomas.

Roberts, R. B., Cowie, D. B., Abelson, P. H., Bolton, E. T. \& Britten, R. J. (1955). Studies of biosynthesis in Escherichia coli. Publ. Carneg. Instn, no. 607, Washington, D.C.

Rogers, H. J. (1954). The rate of formation of hyaluronidase, coagulase, and total extracellular protein by strains of Staphylococcus aureus. J. gen. Microbiol. 10, 209.

Rogers, H. J. (1957). The preferential suppression of hyaluronidase formation in cultures of Staphylococcus aureus. J. gen. Microbiol. 16, 22.

Rogers, H. J. \& Spensley, P. C. (1955). Selective inhibition of the liberation of extracellular enzymes and protein in cultures of Staphylococcus aureus. Biochem. J. 60, 635 .

SheINIn, R. (1956). Some Investigations into the Mechanism of Enzyme Formation. Ph.D. Thesis, University of Toronto.

SpIEgelman, S. (1950). Modern aspects of enzymatic adaptation. In The Enzymes, vol. I, pt. 1, p. 267. Edited by J. B. Sumner and K. Myrbäck. New York: Academic Press Inc.

VoGEL, H. J. (1956). Repression and induction as control mechanisms of enzyme biogenesis: the adaptive formation of acetylornithinase. A Symposium on the Chemical Basis of Heredity, p. 276. Edited by W. D. McElroy and B. Glass. Baltimore: The Johns Hopkins Press.

Vogel, H. J. (1957). Repressed and induced enzyme formation: a unified hypothesis. Proc. nat. Acad. Sci., Wash. 43, 491.

Yates, R. A. \& Pardee, A. B. (1956a). Pyrimidine biosynthesis in Escherichia coli. J. biol. Chem. 221, 743 .

Yates, R. A. \& PARDEe, A. B. $(\mathbf{1 9 5 6} b)$. Control of pyrimidine biosynthesis in Escherichia coli by a feed-back mechanism. J. biol. Chem. 221, 757.

Yates, R. A. \& Pardee, A. B. (1957). Control by uracil of formation of enzymes required for orotate synthesis. J. biol. Chem. 227,677 .

(Received 14 April 1958) 